\title{
Influence of transgenic cotton on the relative abundance and damage by target and non-target insect pests under different protection regimes in India
}

\author{
H.C. Sharma*, G. Pampapathy \\ International Crops Research Institute for the Semi-Arid Tropics (ICRISAT), Patancheru 502 324, Andhra Pradesh, India
}

Received 24 May 2005; received in revised form 26 July 2005; accepted 3 November 2005

\begin{abstract}
Effectiveness of transgenic cottons with Bacillus thuringiensis (Bt) cryl Ac gene along with non-transgenic commercial cultivars of Gossypium hirsutum and G. arboreum for the management of cotton bollworm, Helicoverpa armigera was evaluated at the research farm, International Crops Research Institute for the Semi-Arid Tropics, Patancheru, Andhra Pradesh, India. In general, there were no significant differences in oviposition between the transgenic and the non-transgenic cultivars under protected and unprotected conditions. The larval numbers were significantly lower on the transgenic hybrids during the 2004 rainy season under high infestation, but the differences in larval density between the transgenic and non-transgenic hybrids during 2002 and 2003 seasons under low levels of infestation were quite small. Bollworm damage in squares and bolls was significantly lower in the transgenic hybrids than in the nontransgenic ones, although there were a few exceptions. Differences in seed cotton yield between the transgenic and the non-transgenic hybrids were not significant under unprotected conditions at moderate levels of infestation during the 2002 and 2003 cropping seasons (except in the case of Mech 184). However, significant differences in seed cotton yield were observed during the 2004 cropping season under heavy bollworm infestation. Seed cotton yield of the first picking in transgenic hybrids was significantly greater than that of the non-transgenic counterparts. Transgenic hybrids suffered low shoot damage by spotted bollworm, Earias vittella. However, there were no differences between the transgenic and non-transgenic hybrids in their relative susceptibility to cotton jassid, Amrasca biguttula biguttula and serpentine leaf miner, Liriomyza trifolii, white fly, Bemisia tabaci, green bug, Nezara viridula, ash weevil, Myllocerus undecimpustulatus, and red cotton bug, Dysdercus koenigii. With a few exceptions, the bollworm damage and seed cotton yield of the G. arboreum varieties Aravinda and MDL 2450, and the G. hirsutum variety L 604 was not significantly different than that of the transgenic hybrids, and these varieties were also resistant to cotton jassid. The results suggested that it would be useful to combine transgenic resistance to $H$. armigera with plant characteristics conferring resistance to the target or non-target insect pests in the region in order to realize the full potential of transgenic plants for sustainable crop production.
\end{abstract}

(C) 2005 Elsevier Ltd. All rights reserved.

Keywords: Cotton; Gossypium; Helicoverpa armigera; Non-target pests; Pest management

\section{Introduction}

Cotton bollworm, Helicoverpa armigera (Hubner) (Noctuidae: Lepidoptera), is one of the most devastating pests of cotton, grain legumes, cereals, vegetables, and fruit crops worldwide (Fitt, 1989; Matthews, 1999). It causes an estimated loss of over US\$2 billion annually in the semiarid tropics, despite US\$500 million worth of pesticides

\footnotetext{
${ }^{*}$ Corresponding author. Tel.: + 914030713314 .

E-mail address: h.sharma@egiar.org (H.C. Sharma).
}

applied for controlling this pest (Sharma, 2001). Because of continuous and indiscriminate use of insecticides to minimize the damage caused by $H$. armigera, it has developed high levels of resistance to conventional insecticides (McCaffery et al., 1989; Armes et al., 1996; Kranthi et al., 2002). As a result of evolution of insecticideresistant populations of $H$. armigera, farmers at times resort to frequent use of insecticide mixtures. This has not only resulted in an increase in crop production costs, but has also led to frequent failures in pest control operations and environmental pollution. Therefore, there is a need to 
exploit host plant resistance as a component for the management of $H$. armigera.

The levels of resistance to $H$. armigera in the cultivated germplasm are low to moderate (Sundramurthy and Chitra, 1992; Sharma and Ortiz, 2002), and expression of resistance is not stable over space and time. Some of these problems can be overcome with the recombinant DNA technology, which has enabled the scientists to insert genes for desirable traits into the crop plants in a single event. Transgenic plants with desirable traits were developed in the mid-eighties (Barton et al., 1987; Vaeck et al., 1987), and since then, several crops with resistance to insects have been developed worldwide (Hilder and Boulter, 1999; Sharma et al., 2000, 2004), of which transgenic cottons with toxin genes from Bacillus thuringiensis $(B t)$ have now been widely deployed in the USA, Australia, China, South Africa, and India (James, 2003).

While considerable information has been generated on the relative efficacy of transgenic cottons against the target and non-target insect pests in the USA, Australia, and China (Wilson et al., 1992; Benedict et al., 1996; Guo et al., 1999; Flint et al., 1995; Ni et al., 1996; Schell, 1997; Cui and Xia, 1999; Greenplate, 1999; Fitt, 2003), very little information is available on the relative efficacy of transgenic cottons in minimizing the losses due to target and non-target insect pests in the tropics, where the transgenic plants have been released for cultivation only recently (Qaim and Zilberman, 2003). The cropping systems in tropics are quite complex, and consist of several crops that serve as alternate and collateral hosts of $H$. armigera and other non-target insect pests. Because of the multiplicity pest problems in different crops and cropping systems (mono-, mixed-, inter-, relay-, and sequential-cropping systems), the performance and interactions of transgenic crops are likely to be different in different agro-ecosystems. Therefore, it is important to generate such information under different agro-climatic conditions to take informed decisions about the deploy- ment of insect-resistant transgenic crops for sustainable crop production.

\section{Materials and methods}

Cotton cultivars comprising of Gossypium hirsutum transgenic hybrids with $\operatorname{cryl} A c$ gene from Bt (Mech 12, Mech 162, and Mech 184; Mahyco Seeds Ltd.) and their non-transgenic counterparts, two commercial G. hirsutum varieties (LK 861 and L 604), and two varieties of the indigenous cotton, G. arboreum (Aravinda and MDL 2450) were grown under field conditions on deep black clay soils (Vertisols) under insecticide protected and unprotected conditions during the 2002-2004 rainy seasons at the International Crops Research Institute for the Semi-Arid Tropics, Patancheru, Andhra Pradesh, India. Only one transgenic hybrid (Mech 162) was planted during the 2002 rainy season. The test material was planted in a randomized complete block design, and there were three replications under each protection regime. The seeds were planted on ridges, $75 \mathrm{~cm}$ apart, and each plot had four rows, $4 \mathrm{~m}$ long. The plants were spaced at $50 \mathrm{~cm}$. The crop was planted in the last week of June at the beginning of the rainy season, and raised under rainfed conditions. Normal agronomic practices were followed for raising the crop (basal fertilizer N:P:K::100:40:60 $\mathrm{kg} \mathrm{ha}^{-1}$ ), except the plant protection measures. Carbofuran $3 \mathrm{G}$ granules were applied around the seedlings $\left(3 \mathrm{~g} \mathrm{plant}^{-1}\right)$ at 10 days after seedling emergence in both the protected and unprotected plots to control early damage by the jassid, Amrasca biguttula biguttula Ishida during the 2002 cropping season. Thereafter, no insecticides were applied in the unprotected plots. The insecticide spray schedules for protected plots are given in Table 1. Insecticide application was undertaken with a backpack power sprayer (MS 073F, Maruyama Manufacturing Company Limited). Amount of spray fluid applied was 250-300 $\mathrm{L} \mathrm{ha}^{-1}$ depending upon the crop growth. The protected plots were planted upwind, and

Table 1

Spray schedule for pest management on transgenic and non-transgenic cotton cultivars in different seasons (ICRISAT, Patancheru 2002-2004 rainy seasons)

\begin{tabular}{|c|c|c|c|c|}
\hline $\begin{array}{l}\text { Days after seedling } \\
\text { emergence }\end{array}$ & Target insects & 2002 & 2003 & 2004 \\
\hline$<60$ & Jassids, Bollworms & Monocrotophos SL 36\% & $\begin{array}{l}\text { Monocrotophos SL } 36 \% \\
\text { Methomyl SP } 25 \%\end{array}$ & $\begin{array}{l}\text { Imidacloprid SL } 17.5 \% \\
\text { Methomyl SP } 25 \%\end{array}$ \\
\hline $61-80$ & $\begin{array}{l}\text { Jassids, } \\
\text { Bollworms }\end{array}$ & $\begin{array}{l}\text { Methomyl SP 25\% } \\
\text { Monocrotophos SL 36\% }\end{array}$ & Methomyl SP 25\% & Monocrotophos SL 36\% \\
\hline $81-120$ & $\begin{array}{l}\text { Bollworms, Aphids } \\
\text { Whiteflies }\end{array}$ & $\begin{array}{l}\text { Cypermethrin EC } 25 \% \\
\text { Endosulfan EC } 35 \% \\
\text { Methomyl SP } 25 \%\end{array}$ & $\begin{array}{l}\text { Endosulfan EC } 35 \% \\
\text { Cypermethrin EC } 25 \% \\
\text { Methomyl SP } 25 \%\end{array}$ & $\begin{array}{l}\text { Methomyl SP } 25 \% \\
\text { Cypermethrin EC } 25 \%\end{array}$ \\
\hline$>120$ & Bollworms, Aphids & $\begin{array}{l}\text { Cypermethrin EC 25\% } \\
\text { Monocrotophos SL } 36 \%\end{array}$ & $\begin{array}{l}\text { Cypermethrin EC 25\% } \\
\text { Monocrotophos SL } 36 \% \\
\text { Methomyl SP } 25 \%\end{array}$ & $\begin{array}{l}\text { Monocrotophos SL } 36 \% \\
\text { Methomyl SP } 25 \%\end{array}$ \\
\hline
\end{tabular}

The rates of insecticide application were: $1000{\mathrm{~g} a i \mathrm{~h}^{-1} \text { for monocrotophos, } 500 \mathrm{~g} a i \mathrm{ha}^{-1} \text { for methomyl, } 40 \mathrm{~g} a i \mathrm{ha}^{-1} \text { for cypermethrin, } 700 \mathrm{~g} a \mathrm{i} \text { ha }}^{-1}$ for endosulfan, and $10 \mathrm{~g} a \mathrm{ha} \mathrm{ha}^{-1}$ for imidachloprid. 
separated from the unprotected plots by $3 \mathrm{~m}$. A $3 \times 2 \mathrm{~m}^{2}$ windshield was held downwind between the protected and unprotected plots to reduce any spray drift. Data were recorded on oviposition, larval density, square and bolls damaged by $H$. armigera, and seed cotton yield. Data were also recorded on damage by the non-target insects such as spotted bollworm, Earias vittella (Fab.), cotton jassid, A. biguttula biguttula Ishida, serpentine leaf miner, Liriomyza trifolii (Burgess), ash weevil (Myllocerus undecimpustulatus Faust.), white fly (Bemisia tabaci Guen.), green bug (Nezara viridula L.), and red cotton bug (Dysdercus koenigii Fab.).

\subsection{Egg and larval density and square and boll damage by H. armigera}

\subsubsection{Egg and larval density}

The numbers of eggs and larvae of $H$. armigera were recorded per five plants tagged at random in the center of each plot at 55 and 75, 55 and 80, and 60 and 75 days after seedling emergence at the flowering and boll formation stages during the 2002, 2003, and 2004 rainy seasons, respectively. Numbers of eggs and larvae recorded on five plants over the two observation dates were pooled for each replication for statistical analysis.

\subsubsection{Squares and boll damage}

Squares and bolls damaged by $H$. armigera were recorded in five plants at 90, 80, and 95 days after seedling emergence during the 2002, 2003, and 2004 cropping seasons, respectively. At maturity, numbers of bolls were recorded per five plants at random, and those showing bollworm damage were expressed as a percentage of the total number of bolls. Squares that dropped to the ground were collected at 95 and 90 days after crop emergence during the 2003 and 2004 cropping seasons, respectively, and those damaged by the bollworms were expressed as a percentage of the total number of squares in each plot.

\subsection{Seed cotton yield}

Seed cotton from fully opened bolls was picked up manually, dried in the sun, weighed, and expressed as kilogram per hectare. There were $2-3$ pickings in each

Table 2

Oviposition by Helicoverpa armigera females on Bt-transgenic and non-transgenic cultivars of Gossypium hirsutum and Gossypium arboreum (ICRISAT, Patancheru 2002-2004)

\begin{tabular}{|c|c|c|c|c|c|c|c|c|c|}
\hline \multirow[t]{3}{*}{ Cultivar } & \multicolumn{9}{|c|}{ Number of eggs per five plants } \\
\hline & \multicolumn{3}{|l|}{$2002^{*}$} & \multicolumn{3}{|l|}{$2003^{* *}$} & \multicolumn{3}{|l|}{$2004^{* * *}$} \\
\hline & UP & $\mathrm{CP}$ & Mean & UP & $\mathrm{CP}$ & Mean & UP & $\mathrm{CP}$ & Mean \\
\hline \multicolumn{10}{|c|}{ Gossypium arboreum varieties } \\
\hline Aravinda & 8.3 & 3.7 & $6.0^{\mathrm{ab}}$ & 8.0 & 4.7 & $6.4^{\mathrm{ab}}$ & $6.0^{\mathrm{a}}$ & $8.3^{\mathrm{ab}}$ & 7.2 \\
\hline MDL 2450 & 7.7 & 1.3 & $4.5^{\mathrm{a}}$ & 5.7 & 2.4 & $4.1^{\mathrm{a}}$ & $6.0^{\mathrm{a}}$ & $7.0^{\mathrm{a}}$ & 6.5 \\
\hline \multicolumn{10}{|c|}{ Gossypium hirsutum varieties } \\
\hline L 604 & 17.0 & 8.0 & $12.5^{\mathrm{b}}$ & 21.4 & 13.7 & $17.6^{\mathrm{cd}}$ & $13.0^{\mathrm{abc}}$ & $45.7^{\mathrm{f}}$ & 29.4 \\
\hline LK 861 & 6.3 & 4.7 & $5.5^{\mathrm{a}}$ & 7.0 & 6.0 & $6.5^{\mathrm{ab}}$ & $6.7^{\mathrm{a}}$ & $34.3^{\text {def }}$ & 20.5 \\
\hline \multicolumn{10}{|c|}{ Gossypium hirsutum transgenic hybrids } \\
\hline Mech 12 & - & - & - & 17.0 & 18.7 & $17.9^{\mathrm{cd}}$ & $11.3^{\mathrm{abc}}$ & $33.0^{\mathrm{def}}$ & 22.2 \\
\hline Mech 162 & 24.3 & 14.3 & $19.3^{\mathrm{c}}$ & 19.0 & 30.0 & $24.5^{\mathrm{d}}$ & $10.7^{\mathrm{abc}}$ & $23.7^{\mathrm{cd}}$ & 17.2 \\
\hline Mech 184 & - & - & - & 23.7 & 27.4 & $25.6^{\mathrm{d}}$ & $21.3^{\mathrm{bcd}}$ & $31.7^{\mathrm{de}}$ & 26.5 \\
\hline \multicolumn{10}{|c|}{ Gossypium hirsutum non-transgenic hybrids } \\
\hline Mech 12 & - & - & - & 13.7 & 15.4 & $14.6^{\mathrm{bc}}$ & $3.7^{\mathrm{a}}$ & $28.3^{\mathrm{de}}$ & 16.0 \\
\hline Mech 162 & 15.7 & 23.0 & $19.4^{\mathrm{c}}$ & 22.7 & 17.0 & $19.9^{\mathrm{cd}}$ & $21.3^{\mathrm{bcd}}$ & $28.7^{\mathrm{de}}$ & 25.0 \\
\hline Mech 184 & - & - & - & 21.0 & 23.7 & $22.4^{\mathrm{cd}}$ & $22.3^{\mathrm{cd}}$ & $41.0^{\mathrm{ef}}$ & 31.7 \\
\hline \multirow[t]{2}{*}{ Mean } & $13.2^{\mathrm{B}}$ & $9.2^{\mathrm{A}}$ & 11.2 & 15.9 & 15.9 & 15.9 & $12.2^{\mathrm{A}}$ & $28.2^{\mathrm{B}}$ & 20.2 \\
\hline & $\mathrm{Fp}$ & LSD & & $\mathrm{Fp}$ & LSD & & $\mathrm{Fp}$ & LSD & \\
\hline Genotype (G) & $<0.001$ & 6.56 & & $<0.001$ & 8.39 & & $<0.001$ & 9.42 & \\
\hline Protection $(\mathrm{P})$ & 0.037 & 3.79 & & 0.986 & NS & & $<0.001$ & 4.21 & \\
\hline$G \times P$ & 0.769 & NS & & 0.581 & NS & & 0.015 & 13.33 & \\
\hline
\end{tabular}

UP, unprotected plots; CP, completely protected plots; - , not tested; Fp, probability of $F$-test; LSD, least significant difference at $P<0.05$; NS, nonsignificant. Figures with the same letter in a column or row are not significantly different at $P<0.05$.

*Number of eggs recorded at 55 and 75 days after seedling emergence (DAE).

**Number of eggs recorded at 55 and 80 DAE.

*** Number of eggs recorded at 60 and 75 DAE. 
season, depending upon the length of the growing season. Seed cotton yield was recorded separately for the first and second flush.

\subsection{Effect of transgenic cottons and insecticide sprays on non-target insect pests}

Terminal shoot damage by spotted bollworm, E. vittella was recorded at 55 days after seedling emergence. The numbers of plants with terminal shoot damage in all the four rows in a plot were counted and expressed as a percentage of the total number of plants in each plot. The cotton jassid, A. biguttula biguttula, abundance (adults and nymphs) was recorded on the undersurface of top three fully expanded leaves per five plants selected at random in the middle two rows in each plot at 30 days after seedling emergence. Serpentine leaf miner, $L$. trifolii damage to the leaves was recorded at 30 days after seedling emergence. For this purpose, the total number of leaves and the leaves damaged by the leaf miner per five plants were recorded, and expressed as a percentage of the total number of leaves. Numbers of ash weevil, M. undecimpustulatus were recorded at 45, 60, 75, and 90 days after crop emergence, while the white fly, B. tabaci numbers were carefully recorded on the undersurface of leaves in top three fully expanded leaves in five plants at random in the middle two rows at 90, 110, and 130 days after crop emergence. Numbers of green bug, N. viridula and red cotton bug, D. koenigii were recorded at 110 and 130 days after crop emergence, respectively. Since the numbers of some of these non-targets insects were quite low, their numbers were pooled across observation dates for purposes of data analysis and interpretation.

\subsection{Statistical analysis}

Total numbers of insects across observation dates were pooled for statistical analysis. The data were subjected to factorial analysis, with genotypes as the main treatment, and protection levels as the sub-treatment. The significance of differences between the treatments was judged by $F$-test, while the significance of differences between the treatment means was judged by least significant difference (LSD) at $P \leqslant 0.05$. When the interaction effects were non-significant,

Table 3

Abundance of Helicoverpa armigera larvae on Bt-transgenic and non-transgenic cultivars of Gossypium hirsutum and Gossypium arboreum (ICRISAT, Patancheru 2002-2004)

\begin{tabular}{|c|c|c|c|c|c|c|c|c|c|}
\hline Cultivar & \multicolumn{9}{|c|}{ Number of larvae per five plants } \\
\hline \multicolumn{10}{|c|}{ Gossypium arboreum varieties } \\
\hline Aravinda & 0.0 & 0.0 & 0.0 & 2.6 & 2.5 & $2.6^{\mathrm{bc}}$ & $1.0^{\mathrm{ab}}$ & $2.3^{\mathrm{abc}}$ & 1.7 \\
\hline MDL 2450 & 0.7 & 0.3 & 0.5 & 0.6 & 0.9 & $0.8^{\mathrm{ab}}$ & $0.7^{\mathrm{ab}}$ & $2.0^{\mathrm{abc}}$ & 1.4 \\
\hline L 604 & 1.7 & 0.3 & 1.0 & 2.1 & 2.5 & $2.3^{\mathrm{ab}}$ & $1.0^{\mathrm{ab}}$ & $8.3^{\mathrm{de}}$ & 4.7 \\
\hline LK 861 & 1.7 & 0.7 & 1.2 & 1.2 & 1.0 & $1.1^{\mathrm{ab}}$ & $1.3^{\mathrm{ab}}$ & $5.0^{\mathrm{cd}}$ & 3.2 \\
\hline \multicolumn{10}{|c|}{ Gossypium hirsutum transgenic hybrids } \\
\hline Mech 12 & - & - & - & 0.6 & 0.0 & $0.3^{\mathrm{a}}$ & $0.0^{\mathrm{a}}$ & $2.3^{\mathrm{abc}}$ & 1.2 \\
\hline Mech 162 & 2.7 & 1.3 & 2.0 & 0.6 & 0.6 & $0.6^{\mathrm{ab}}$ & $1.0^{\mathrm{ab}}$ & $3.7^{\mathrm{bc}}$ & 2.4 \\
\hline Mech 184 & - & - & - & 3.1 & 2.0 & $2.6^{\mathrm{bc}}$ & $1.0^{\mathrm{ab}}$ & $5.0^{\mathrm{cd}}$ & 3.0 \\
\hline Mech 184 & - & - & - & 3.8 & 5.4 & $4.6^{\mathrm{c}}$ & $3.7^{\mathrm{bc}}$ & $13.7^{\mathrm{g}}$ & 8.7 \\
\hline \multirow[t]{2}{*}{ Mean } & $1.6^{\mathrm{B}}$ & $0.6^{\mathrm{A}}$ & 1.1 & 1.7 & 1.9 & 1.8 & $1.3^{\mathrm{A}}$ & $6.5^{\mathrm{B}}$ & 3.9 \\
\hline & $\mathrm{Fp}$ & LSD & & $\mathrm{Fp}$ & LSD & & $\mathrm{Fp}$ & LSD & \\
\hline Genotype (G) & 0.303 & NS & & 0.011 & 2.24 & & $<0.001$ & 2.51 & \\
\hline Protection $(\mathrm{P})$ & 0.016 & 0.80 & & 0.722 & NS & & $<0.001$ & 1.12 & \\
\hline $\mathrm{G} \times \mathrm{P}$ & 0.142 & NS & & 0.989 & NS & & $<0.001$ & 3.55 & \\
\hline
\end{tabular}

UP, unprotected plots; CP, completely protected plots; - , not tested; Fp, probability of $F$-test; LSD, least significant difference at $P<0.05$; NS, nonsignificant. Figures with the same letter in a column or row are not significantly different at $P<0.05$.

*Number of larvae recorded at 55 and 75 days after seedling emergence (DAE).

**Number of larvae recorded at 55 and 80 DAE.

*** Number of larvae recorded at 60 and 75 DAE. 
the means for genotypes and protection regimes were separated by the respective values for LSD. In case, the interaction effects were significant, the genotype means in protected and unprotected regimes were separated by the LSD for interaction effects.

\section{Results}

\subsection{Effect of transgenic cottons and protection regimes} on oviposition, larval density, and square and boll damage by $H$. armigera

\subsubsection{Oviposition}

There were significant differences (at $P<0.05$ ) in numbers of eggs laid among the genotypes tested, and protection levels (except during the 2003 cropping season). The interaction effects were non-significant, except during the 2004 cropping season (Table 2). Significantly lower numbers of eggs were recorded on the $G$. arboreum varieties Aravinda and MDL 2450 (1.3-8.3 eggs 5 plants $^{-1}$ ), and the G. hirsutum variety, LK 861 (4.7-6.7 eggs 5 plants $^{-1}$, except in the 2004 rainy season when there were
34.3 eggs 5 plants $\left.^{-1}\right)$ as compared to the transgenic (10.7-33.0 eggs) or non-transgenic hybrids (3.7-41.0 eggs), and the $G$. hirsutum variety L 604 (8.0-45.7 eggs). Differences in egg numbers between the protected and unprotected plots were quite large and significant during the 2004 cropping season under heavy infestation of $H$. armigera. The numbers of eggs laid were more in the insecticide protected plots in G. hirsutum varieties and hybrids, possibly because of more vegetative growth under insecticide protected conditions. There were no significant differences in eggs laid between the $B t$-transgenic hybrids and their non-transgenic counterparts. Cotton hybrid Mech 12, which has smooth leaves, was less preferred for oviposition as compared to Mech 184, which was more hairy than the other hybrids tested.

\subsubsection{Larval density}

Differences in larval numbers were non-significant among the genotypes tested during the 2002 cropping season (Table 3). Differences in larval numbers across protection levels (except in 2002), interaction effects, and between the transgenic and non-transgenic hybrids were

Table 4

Square damage by Helicoverpa armigera on Bt-transgenic and non-transgenic cultivars of Gossypium hirsutum and Gossypium arboreum (ICRISAT, Patancheru 2002/04)

\begin{tabular}{|c|c|c|c|c|c|c|c|c|c|c|c|c|c|c|c|}
\hline \multirow[t]{3}{*}{ Cultivar } & \multicolumn{9}{|c|}{ Square damage $(\%)$} & \multicolumn{6}{|c|}{ Damage in shed squares $(\%)^{*}$} \\
\hline & \multicolumn{3}{|l|}{2002} & \multicolumn{3}{|l|}{2003} & \multicolumn{3}{|l|}{2004} & \multicolumn{3}{|l|}{$\begin{array}{l}2003 \\
95 \text { DAE }\end{array}$} & \multicolumn{3}{|l|}{$\begin{array}{l}2004 \\
90 \mathrm{DAE}\end{array}$} \\
\hline & UP & $\mathrm{CP}$ & Mean & UP & $\mathrm{CP}$ & Mean & UP & $\mathrm{CP}$ & Mean & UP & $\mathrm{CP}$ & Mean & UP & $\mathrm{CP}$ & Mean \\
\hline \multicolumn{16}{|c|}{ Gossypium arboreum varieties } \\
\hline Aravinda & 3.7 & 10.5 & $7.1^{\mathrm{ab}}$ & $1.3^{\mathrm{a}}$ & $4.2^{\mathrm{abcd}}$ & 2.8 & $4.5^{\mathrm{abc}}$ & $6.7^{\text {abcde }}$ & 5.6 & 62.4 & 59.4 & $60.9^{\mathrm{d}}$ & $9.6^{\mathrm{abc}}$ & $6.1^{\text {cde }}$ & 7.9 \\
\hline MDL 2450 & 3.5 & 6.5 & $5.0^{\mathrm{a}}$ & $3.4^{\mathrm{abcd}}$ & $3.3^{\mathrm{abcd}}$ & 3.4 & $2.9^{\mathrm{ab}}$ & $2.6^{\mathrm{ab}}$ & 2.8 & 36.3 & 17.8 & $27.1^{\mathrm{ab}}$ & $5.6^{\mathrm{a}}$ & $5.2^{\mathrm{a}}$ & 5.4 \\
\hline \multicolumn{16}{|c|}{ Gossypium hirsutum varieties } \\
\hline L 604 & 15.3 & 30.5 & $22.9^{\mathrm{c}}$ & $5.5^{\mathrm{bcd}}$ & $4.1^{\mathrm{abcd}}$ & 4.8 & $8.5^{\text {abcde }}$ & $19.5^{\mathrm{gh}}$ & 14.0 & 32.8 & 39.4 & $36.1^{\mathrm{abc}}$ & $17.7^{\mathrm{def}}$ & $10.1^{\mathrm{abc}}$ & 13.9 \\
\hline LK 861 & 7.5 & 19.0 & $13.3^{\mathrm{b}}$ & $5.9^{\mathrm{cd}}$ & $1.6^{\mathrm{a}}$ & 3.8 & $10.1^{\text {bcdef }}$ & $16.7^{\mathrm{efgh}}$ & 13.4 & 48.5 & 32.4 & $40.5^{\mathrm{bc}}$ & $16.1^{\mathrm{cde}}$ & $16.0^{\text {cde }}$ & 16.1 \\
\hline \multicolumn{16}{|c|}{ Gossypium hirsutum transgenic hybrids } \\
\hline Mech 12 & - & - & - & $1.0^{\mathrm{a}}$ & $1.6^{\mathrm{a}}$ & 1.3 & $2.2^{\mathrm{a}}$ & $4.6^{\mathrm{abc}}$ & 3.4 & 13.4 & 41.6 & $27.5^{\mathrm{ab}}$ & $6.6^{\mathrm{a}}$ & $4.1^{\mathrm{a}}$ & 5.4 \\
\hline Mech 162 & 9.7 & 13.6 & $11.7^{\mathrm{b}}$ & $1.1^{\mathrm{a}}$ & $3.7^{\mathrm{abcd}}$ & 2.4 & $6.0^{\mathrm{abcd}}$ & $9.2^{\text {abcdef }}$ & 7.6 & 14.6 & 23.3 & $19.0^{\mathrm{a}}$ & $7.3^{\mathrm{ab}}$ & $7.4^{\mathrm{ab}}$ & 7.4 \\
\hline Mech 184 & - & - & - & $3.0^{\mathrm{abcd}}$ & $1.9^{\mathrm{a}}$ & 2.5 & $1.4^{\mathrm{a}}$ & $10.9^{\text {cdef }}$ & 6.2 & 41.9 & 37.1 & $39.5^{\mathrm{bc}}$ & $9.0^{\mathrm{abc}}$ & $10.1^{\mathrm{abc}}$ & 9.6 \\
\hline \multicolumn{16}{|c|}{ Gossypium hirsutum non-transgenic hybrids } \\
\hline Mech 12 & - & - & - & $2.5^{\mathrm{abc}}$ & $2.2^{\mathrm{ab}}$ & 2.4 & $3.9^{\mathrm{abc}}$ & $14.0^{\mathrm{efg}}$ & 9.0 & 46.2 & 59.7 & $53.0^{\mathrm{cd}}$ & $14.7^{\mathrm{bcd}}$ & $10.9^{\mathrm{abcd}}$ & 12.8 \\
\hline Mech 162 & 17.7 & 30.6 & $24.2^{\mathrm{c}}$ & $1.5^{\mathrm{a}}$ & $6.3^{\mathrm{d}}$ & 3.9 & $10.3^{\text {bcdef }}$ & $22.0^{\mathrm{h}}$ & 16.2 & 33.8 & 41.2 & $37.5^{\mathrm{bc}}$ & $23.7^{\mathrm{b}}$ & $10.8^{\mathrm{abcd}}$ & 17.3 \\
\hline Mech 184 & - & - & & $5.6^{\mathrm{bcd}}$ & $5.8^{\mathrm{cd}}$ & 5.7 & $12.8^{\operatorname{defg}}$ & $30.9^{\mathrm{g}}$ & 21.9 & 73.5 & 58.7 & $66.1^{\mathrm{d}}$ & $16.2^{\text {cde }}$ & $22.2^{\mathrm{ef}}$ & 19.2 \\
\hline \multirow[t]{2}{*}{ Mean } & $9.6^{\mathrm{A}}$ & $18.5^{\mathrm{B}}$ & 14.0 & 3.1 & 3.5 & 3.3 & 6.3 & 13.7 & 10.0 & 40.3 & 41.1 & 40.7 & 12.7 & 10.3 & 11.5 \\
\hline & $\mathrm{Fp}$ & LSD & & $\mathrm{Fp}$ & LSD & & $\mathrm{Fp}$ & LSD & & $\mathrm{Fp}$ & LSD & & $\mathrm{Fp}$ & LSD & \\
\hline Genotype (G) & $<0.001$ & 6.52 & & 0.033 & 2.45 & & $<0.001$ & 5.51 & & $<0.001$ & 18.02 & & $<0.001$ & 5.27 & \\
\hline Protection $(\mathrm{P})$ & $<0.001$ & 3.26 & & 0.501 & NS & & $<0.001$ & 2.47 & & 0.859 & NS & & 0.006 & 2.36 & \\
\hline $\mathrm{G} \times \mathrm{P}$ & 0.270 & NS & & 0.044 & 3.46 & & 0.048 & 7.80 & & 0.223 & NS & & 0.034 & 7.45 & \\
\hline
\end{tabular}

DAE, days after seedling emergence; Fp, probability of $F$-test; UP, un-protected; CP, completely protected; LSD, least significant difference at $P<0.05$; NS, non-significant. Figures with the same letter in a column or row are not significantly different at $P<0.05$.

* Shed squares collected from the ground during 2003 and 2004. 
non-significant during the 2002 and 2003 cropping seasons, when the larval density was comparatively low. During the 2004 cropping season, the differences among the genotypes tested, protection levels, and the interaction effects were significant. Larval density was lower (2.35.0 larvae 5 plants $^{-1}$ ) on the transgenic hybrids as compared to the non-transgenic counterparts (9.713.7 larvae 5 plants $^{-1}$ ) under protected conditions. Numbers of $H$. armigera larvae were also lower (0.62.6 larvae 5 plants $^{-1}$ ) on the G. arboreum (Aravinda and MDL 2450) and G. hirsutum (LK 861) varieties as compared to the non-transgenic hybrids under protected conditions. However, under unprotected conditions, the differences between the genotypes tested were non-significant, except for Mech 184. There were more larvae in the protected than in the unprotected plots during the 2004 rainy season because of more oviposition as a result of better vegetative growth due to insecticide protection during the early stages.

\subsubsection{Bollworm damage in squares}

Differences in bollworm damage in squares on the plants were significant among the genotypes, protection levels (except during the 2003 cropping season), and the interaction effects (except during the 2002 cropping season)
(Table 4). During the 2002 and 2003 cropping seasons, when the $H$. armigera infestation was low, the percentage of damaged squares was lower in G. arboreum varieties Aravinda and MDL 2450 than on the non-transgenic hybrid Mech 162 during the 2002 cropping season, and Mech 184 during the 2003 cropping season. During the 2004 cropping season, when the $H$. armigera infestation was relatively high, the square damage was lower on the G. arboreum varieties Aravinda and MDL 2450, and the transgenic hybrids than on the non-transgenic hybrids Mech 12, Mech 162, and Mech 184 (except in Mech 12 and Mech 162 under unprotected conditions). The square damage was greater in protected plots than in the unprotected ones (except during the 2003 cropping season), possibly because of more plant canopy due to low damage by the sucking insects.

There were significant differences in $H$. armigera damage in squares that dropped to the ground among the genotypes tested. However, the differences between the protection levels and the interaction effects were significant only during the 2004 cropping season. Square damage was lower in transgenic hybrids than in the non-transgenic counterparts (except in Mech 12 and Mech 162 during the 2004 cropping season). Damage to squares in Mech 184 was higher (except in 2004 rainy season) than on the other

Table 5

Helicoverpa armigera damage in bolls of Bt-transgenic and non-transgenic cultivars of Gossypium hirsutum and Gossypium arboreum (ICRISAT, Patancheru 2002/04)

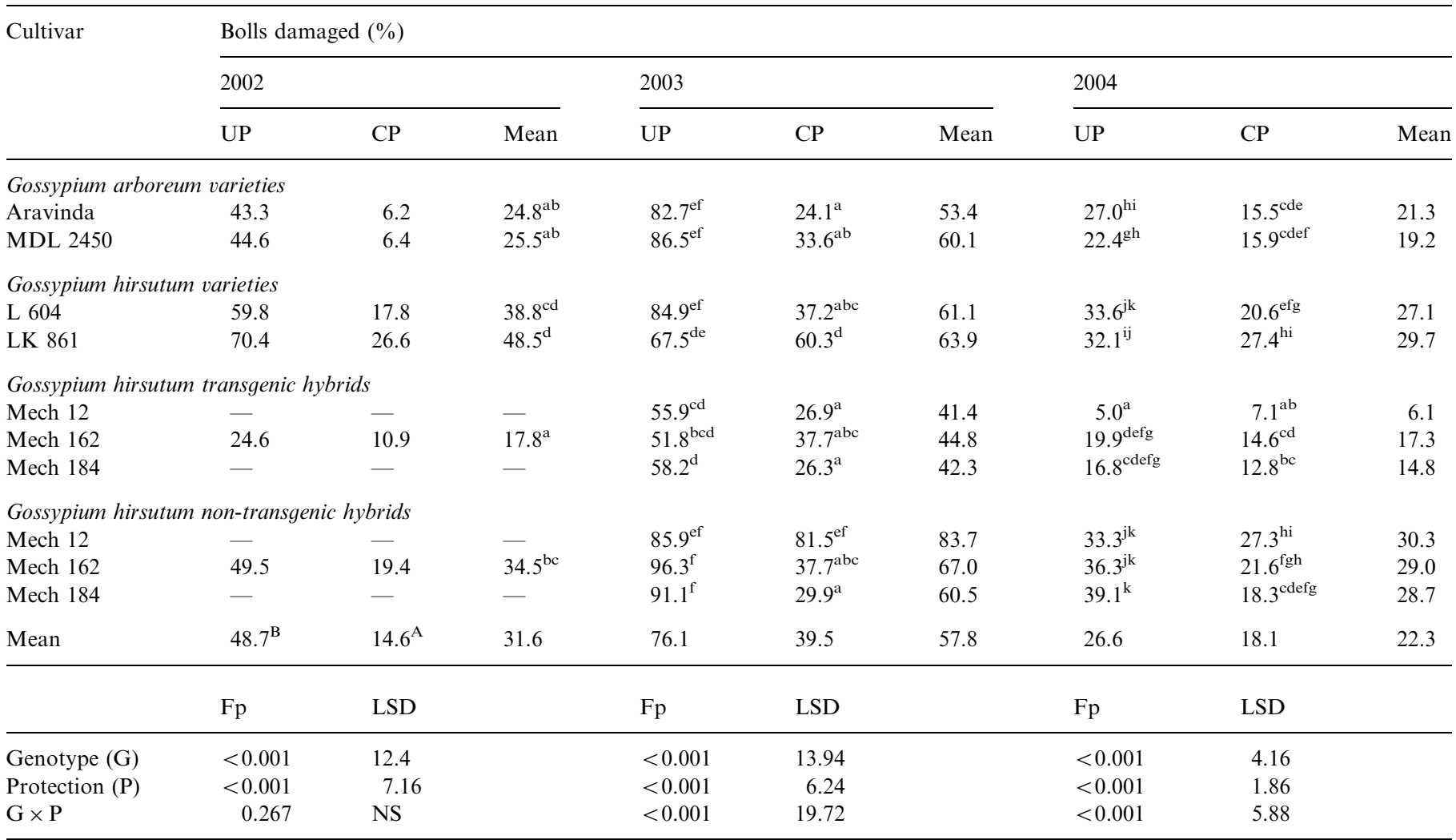

UP, un-protected; CP, completely protected; - not tested; Fp, probability of $F$-test; LSD, least significant difference at $P<0.05$; NS, non-significant. Figures with the same letter in a column or row are not significantly different at $P<0.05$. 
transgenic hybrids tested possibly because of high oviposition. Insecticide protection showed little influence on $H$. armigera damage in shed squares as most of the damaged squares dropped to the ground.

\subsubsection{Bollworm damage in bolls}

There were significant differences in boll damage among the genotypes tested and protection levels (Table 5). The interaction effects were also significant (except during the 2002 cropping season). Damage to the bolls was lower in the transgenic hybrids than in the non-transgenic counterparts (except in Mech 162 and Mech 184 under protected conditions during the 2003 cropping season). Damage to the bolls was lower in the transgenic hybrids under protected conditions as compared to that under unprotected conditions (except in Mech 12 and Mech 184 during the 2004 cropping season). Bollworm infestation in the non-transgenic varieties and hybrids was quite high.

\subsection{Effect of transgenic cotton and protection regimes on seed cotton yield}

There were significant differences in seed cotton yield among the genotypes, protection levels, and the interaction effects (except during the 2002 cropping season) (Table 6).
Under unprotected conditions, the G. arboreum variety MDL 2450 produced the highest seed cotton yield $\left(2953 \mathrm{~kg} \mathrm{ha}^{-1}\right)$, and the G. hirsutum variety LK 861 , the least $\left(339 \mathrm{~kg} \mathrm{ha}^{-1}\right)$ during the 2002 cropping season. Seed cotton yield was significantly greater in the transgenic cotton hybrid Mech $162\left(2886 \mathrm{~kg} \mathrm{ha}^{-1}\right)$ than its nontransgenic counterpart $\left(2040 \mathrm{~kg} \mathrm{ha}^{-1}\right)$. Under completely protected conditions, the highest seed cotton yield was recorded in MDL $2450\left(4429 \mathrm{~kg} \mathrm{ha}^{-1}\right)$, followed by the transgenic hybrid Mech $162\left(3359 \mathrm{~kg} \mathrm{ha}^{-1}\right)$. During the 2003 cropping season, highest seed cotton yield was obtained in plots of transgenic hybrid Mech 184 $\left(3709 \mathrm{~kg} \mathrm{ha}^{-1}\right)$ and least in plots of LK $861\left(1436 \mathrm{~kg} \mathrm{ha}^{-1}\right)$ under protected conditions. The differences in seed cotton yield between the transgenic and the non-transgenic hybrids were non-significant (except in case of Mech 184). The seed cotton yield of $G$. arboreum variety Aravinda was not significantly different than that of transgenic or non-transgenic hybrids under protected conditions. During the 2004 cropping season, the seed cotton yield of transgenic hybrids was significantly greater than their non-transgenic counterparts under both protected and unprotected conditions (except Mech 12 and Mech 162 under unprotected conditions). The seed cotton yield of first flush was much greater in the transgenic

Table 6

Seed cotton yield of Bt-transgenic and non-transgenic commercial cultivars of Gossypium hirsutum and Gossypium arboreum (ICRISAT, Patancheru, 2002/04)

\begin{tabular}{|c|c|c|c|c|c|c|c|c|c|}
\hline \multirow[t]{2}{*}{ Cultivar } & \multicolumn{9}{|c|}{ Seed cotton yield $\left(\mathrm{kg} \mathrm{ha}^{-1}\right)$} \\
\hline & \multicolumn{3}{|l|}{2002} & \multicolumn{3}{|l|}{2003} & \multicolumn{3}{|l|}{2004} \\
\hline \multicolumn{10}{|c|}{ Gossypium arboreum varieties } \\
\hline Aravinda & 1653 & 2823 & $2238^{\mathrm{b}}$ & $1060^{\text {bcd }}$ & $2416^{\mathrm{gh}}$ & 1738 & $1252^{\mathrm{efg}}$ & $2583^{\mathrm{i}}$ & 1918 \\
\hline MDL 2450 & 2952 & 4428 & $3690^{\mathrm{d}}$ & $933^{\mathrm{abc}}$ & $2053^{\mathrm{fg}}$ & 1493 & $872^{\text {bcde }}$ & $4293^{\mathrm{k}}$ & 2583 \\
\hline L 604 & 1151 & 1889 & $1520^{\mathrm{a}}$ & $371^{\mathrm{a}}$ & $1980^{\text {efg }}$ & 1176 & $551^{\mathrm{abc}}$ & $1371^{\mathrm{fgh}}$ & 961 \\
\hline LK 861 & 338 & 961 & $650^{\mathrm{a}}$ & $351^{\mathrm{a}}$ & $1436^{\text {cde }}$ & 894 & $228^{\mathrm{a}}$ & $1813^{\mathrm{h}}$ & 1021 \\
\hline \multicolumn{10}{|c|}{ Gossypium hirsutum transgenic hybrids } \\
\hline Mech 12 & - & - & - & $476^{\mathrm{ab}}$ & $1558^{\mathrm{def}}$ & 1017 & $638^{\text {abcd }}$ & $3093^{\mathrm{j}}$ & 1866 \\
\hline Mech 162 & 2886 & 3359 & $3123^{\mathrm{c}}$ & $638^{\mathrm{ab}}$ & $2683^{\mathrm{h}}$ & 1661 & $949^{\text {cdef }}$ & $2883^{\mathrm{ij}}$ & 1916 \\
\hline Mech 184 & - & - & - & $1571^{\text {def }}$ & $3708^{\mathrm{i}}$ & 2640 & $2855^{\mathrm{ij}}$ & $2978^{\mathrm{ij}}$ & 2917 \\
\hline Mech 184 & - & - & - & $769^{\mathrm{ab}}$ & $2643^{\mathrm{h}}$ & 1706 & $1130^{\text {defg }}$ & $1135^{\text {efg }}$ & 1133 \\
\hline \multirow[t]{2}{*}{ Mean } & $1837^{\mathrm{A}}$ & $2616^{\mathrm{B}}$ & 2226 & 752 & 2286 & 1519 & 973 & 2315 & 1644 \\
\hline & $\mathrm{Fp}$ & LSD & & $\mathrm{Fp}$ & LSD & & $\mathrm{Fp}$ & LSD & \\
\hline Genotypes (G) & $<0.001$ & 527.2 & & $<0.001$ & 423.1 & & $<0.001$ & 349.6 & \\
\hline Protection levels $(\mathrm{P})$ & $<0.001$ & 304.4 & & $<0.001$ & 189.2 & & $<0.001$ & 156.4 & \\
\hline $\mathrm{G} \times \mathrm{P}$ & 0.106 & NS & & 0.023 & 588.4 & & $<0.001$ & 494.5 & \\
\hline
\end{tabular}

UP, unprotected; CP, completely protected; Fp, probability of $F$-test; LSD, least significant difference at $P<0.05$; NS, non-significant. Figures with the same letter in a column or row are not significantly different at $P<0.05$. 

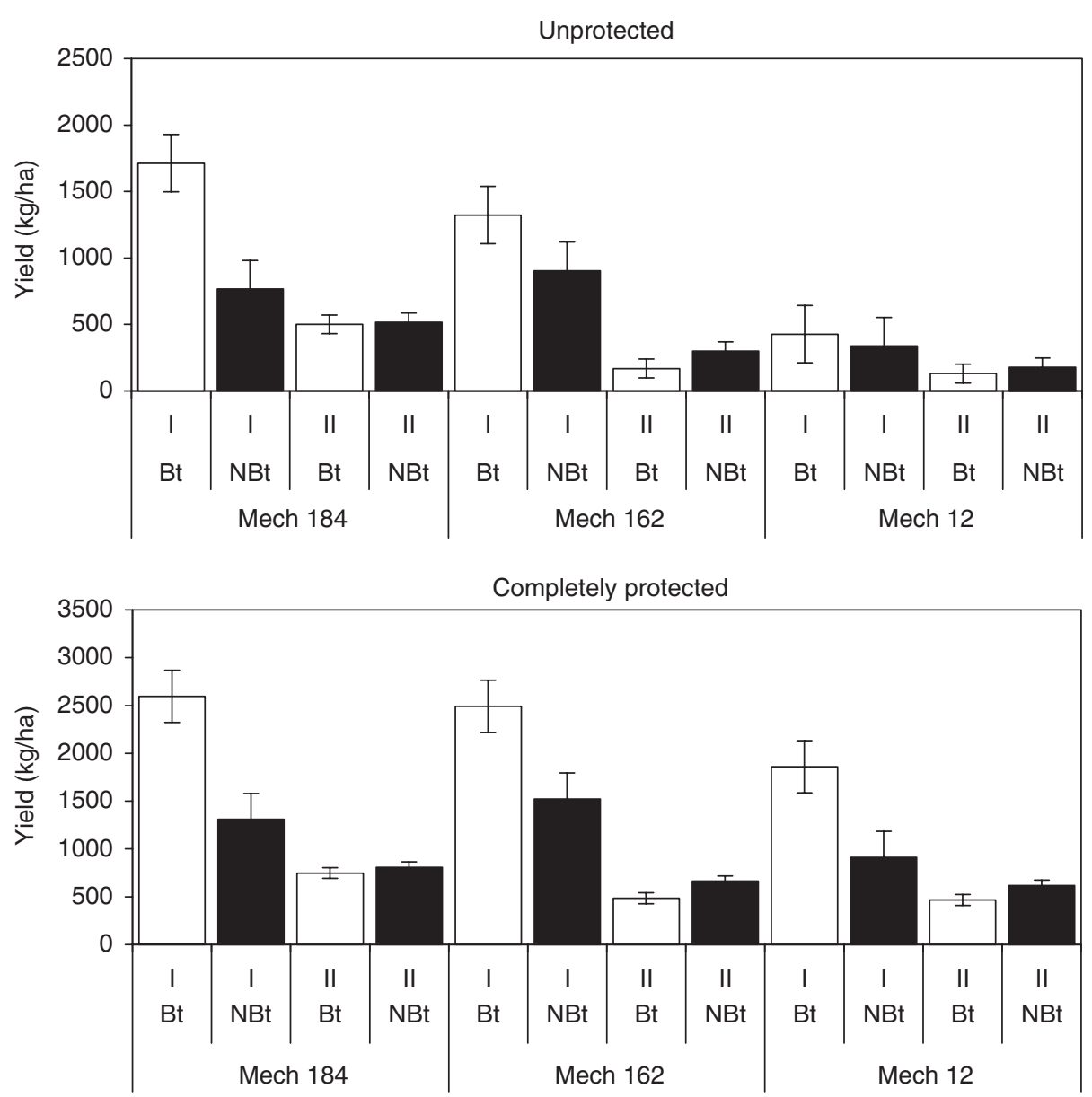

Fig. 1. Seed cotton yield of first (I) and second (II) flush in the transgenic and the non-transgenic cultivars under unprotected and completely protected conditions. Bt, transgenic hybrid and NBt, non-transgenic hybrid.

hybrids than their non-transgenic counterparts, both under unprotected and protected conditions. However, the second flush was marginally more in the non-transgenic hybrids than that of the transgenic ones (Fig. 1). The seed cotton yield of $G$. hirsutum varieties was quite low because of their greater susceptibility to jassids and bollworms, while the $G$. arboreum varieties were on par with the transgenic hybrids because of their inherent resistance to jassids and bollworms. The seed cotton yield of the transgenic hybrids was cleaner (lower proportion of insect stained lint) than in the non-transgenic counterparts, although no specific data were recorded on this aspect.

\subsection{Effect of transgenic cottons and protection regimes on non-target insect pests}

\subsubsection{Shoot damage by spotted bollworm}

Differences in shoot damage by the spotted bollworm, $E$. vittella, were significant between the genotypes tested during the 2004 cropping season (Table 7). Shoot damage in the transgenic hybrids was significantly lower $(0-9.6 \%$ shoot damage) than in the non-transgenic counterparts $(8.7-46.7 \%)$. Differences in shoot damage across protec- tion regimes were not large as very little insecticide was applied during the vegetative phase. No shoot damage was observed during the 2003 rainy season. Gossypium hirsutum variety, LK 861 and G. arboreum variety Aravinda (except in 2004 under unprotected conditions) also suffered low shoot damage by $E$. vittella.

\subsubsection{Cotton jassid}

The differences in jassid, A. biguttula biguttula numbers were significant among the genotypes tested across seasons (Table 8). However, there were no differences across protection regimes as very little insecticide was used during the vegetative phase. The interaction effects were also nonsignificant. The numbers of jassids under unprotected conditions were lower $\left(5.0-6.4\right.$ jassids 5 plants $\left.^{-1}\right)$ on the transgenic hybrid Mech 162 and its non-transgenic counterpart, and the G. arboreum varieties, Aravinda and MDL 2450 (2.4-5.7 jassids 5 plants $\left.^{-1}\right)$ as compared to the G. hirsutum varieties, L 604 and LK 861 (24.437.0 jassids 5 plants $^{-1}$ ) during the 2002 cropping season. Very few jassids were present during the observation period on the leaves of transgenic and non-transgenic versions of Mech 162 hybrid during the 2002 rainy season because 
Table 7

Shoot damage by spotted bollworm, Earias vittella in Bt-transgenic and non-transgenic cultivars of Gossypium hirsutum and Gossypium arboreum (ICRISAT, Patancheru, 2002-2004)

\begin{tabular}{|c|c|c|c|c|c|c|}
\hline \multirow[t]{3}{*}{ Cultivar } & \multicolumn{6}{|c|}{ Shoot damage (\%) (55 DAE) } \\
\hline & \multicolumn{3}{|l|}{2002} & \multicolumn{3}{|l|}{2004} \\
\hline & UP & $\mathrm{CP}$ & Mean & Mean & $\mathrm{CP}$ & Mean \\
\hline \multicolumn{7}{|c|}{ Gossypium arboreum varieties } \\
\hline Aravinda & 13.3 & 13.3 & 13.3 & 30.0 & 17.2 & $23.6^{\mathrm{f}}$ \\
\hline MDL 2450 & 26.7 & 20.0 & 23.4 & 16.3 & 25.2 & $20.8^{\mathrm{ef}}$ \\
\hline \multicolumn{7}{|c|}{ Gossypium hirsutum varieties } \\
\hline L 604 & 20.0 & 26.7 & 23.4 & 20.7 & 18.7 & $19.7^{\mathrm{def}}$ \\
\hline LK 861 & 20.0 & 13.3 & 16.7 & 11.8 & 5.8 & $8.8^{\mathrm{abc}}$ \\
\hline \multicolumn{7}{|c|}{ Gossypium hirsutum transgenic hybrids } \\
\hline Mech 12 & - & - & - & 0.0 & 9.6 & $4.8^{\mathrm{abc}}$ \\
\hline Mech 162 & 6.7 & 6.7 & 6.7 & 2.8 & 1.4 & $2.1^{\mathrm{a}}$ \\
\hline Mech 184 & - & - & - & 0.0 & 6.9 & $3.5^{\mathrm{ab}}$ \\
\hline \multicolumn{7}{|c|}{ Gossypium hirsutum non-transgenic hybrids } \\
\hline Mech 12 & - & - & - & 8.7 & 13.9 & $11.3^{\mathrm{bcd}}$ \\
\hline Mech 162 & 26.7 & 46.7 & 36.7 & 15.5 & 10.0 & $12.8^{\text {cde }}$ \\
\hline Mech 184 & - & - & & 22.5 & 12.6 & $17.6^{\mathrm{def}}$ \\
\hline \multirow[t]{2}{*}{ Mean } & 18.9 & 21.1 & 20.0 & 12.8 & 12.1 & 12.5 \\
\hline & $\mathrm{Fp}$ & LSD & & $\mathrm{Fp}$ & LSD & \\
\hline Genotype (G) & 0.231 & NS & & $<0.001$ & 8.661 & \\
\hline Protection $(\mathrm{P})$ & 0.750 & NS & & 0.718 & NS & \\
\hline $\mathrm{G} \times \mathrm{P}$ & 0.874 & NS & & 0.108 & NS & \\
\hline
\end{tabular}

UP, unprotected; CP, completely protected; - , not tested; Fp, probability of $F$-test; DAE, days after seedling emergence; LSD, least significant difference at $P<0.05$; NS, non-significant. Figures with the same letter in a column or row are not significantly different at $P<0.05$.

of heavy damage at the seedling stage. During the 2003 and 2004 cropping seasons, the jassid numbers were lower on the G. arboreum varieties Aravinda and MDL 2450 and the transgenic and non-transgenic versions of the hybrid Mech 184, while the G. hirsutum variety L 604 showed moderate levels of susceptibility to A. biguttula biguttula. There were no differences in jassid numbers between the transgenic and the respective non-transgenic hybrids. However, jassid numbers were lower on Mech 184 because of its hairiness compared with the other hybrids tested.

\subsubsection{Serpentine leaf miner}

There were significant differences in leaf damage by the serpentine leaf miner, L. trifolii, among the genotypes tested. However, the differences across protection levels (except during the 2004 cropping season) and the interaction effects were non-significant (Table 9). There were no differences in leaf miner damage between the transgenic and the non-transgenic hybrids. However, leaf miner damage was significantly lower on the G. arboreum varieties, Aravinda and MDL 2450 than in the G. hirsutum
Table 8

Relative abundance of cotton jassid, Amrasca biguttula biguttula on Bttransgenic and non-transgenic cultivars of Gossypium hirsutum and Gossypium arboreum (ICRISAT, Patancheru, 2002-2004)

\begin{tabular}{|c|c|c|c|c|c|c|}
\hline \multirow[t]{3}{*}{ Cultivar } & \multicolumn{6}{|c|}{ Number of jassids per five leaves (30 DAE) } \\
\hline & \multicolumn{3}{|l|}{2002} & \multicolumn{3}{|l|}{2004} \\
\hline & UP & $\mathrm{CP}$ & Mean & Mean & $\mathrm{CP}$ & Mean \\
\hline \multicolumn{7}{|c|}{ Gossypium arboreum varieties } \\
\hline Aravinda & 14.8 & 14.6 & $14.7^{\mathrm{a}}$ & 20.3 & 28.5 & $24.4^{\mathrm{a}}$ \\
\hline MDL 2450 & 12.3 & 7.4 & $9.9^{\mathrm{a}}$ & 17.2 & 29.6 & $23.4^{\mathrm{a}}$ \\
\hline \multicolumn{7}{|c|}{ Gossypium hirsutum varieties } \\
\hline L 604 & 24.9 & 26.7 & $25.8^{\mathrm{b}}$ & 34.0 & 43.0 & $38.5^{\mathrm{b}}$ \\
\hline LK 861 & 37.5 & 34.1 & $35.8^{\mathrm{c}}$ & 45.1 & 44.1 & $44.6^{\mathrm{c}}$ \\
\hline \multicolumn{7}{|c|}{ Gossypium hirsutum transgenic hybrids } \\
\hline Mech 12 & - & - & - & 47.2 & 50.0 & $48.6^{\mathrm{cd}}$ \\
\hline Mech 162 & 26.7 & 32.5 & $29.6^{\mathrm{b}}$ & 47.8 & 47.9 & $47.9^{\mathrm{cd}}$ \\
\hline Mech 184 & - & - & - & 47.7 & 50.8 & $49.3^{\mathrm{cd}}$ \\
\hline \multicolumn{7}{|c|}{ Gossypium hirsutum non-transgenic hybrids } \\
\hline Mech 12 & - & - & - & 49.6 & 52.2 & $50.9^{\mathrm{d}}$ \\
\hline Mech 162 & 29.5 & 32.3 & $30.9^{\mathrm{bc}}$ & 49.9 & 50.4 & $50.2^{\mathrm{d}}$ \\
\hline Mech 184 & - & - & - & 43.4 & 52.8 & $48.1^{\mathrm{cd}}$ \\
\hline \multirow[t]{2}{*}{ Mean } & 24.3 & 24.6 & 24.4 & $40.2^{\mathrm{A}}$ & $44.9^{\mathrm{B}}$ & 42.6 \\
\hline & $\mathrm{Fp}$ & LSD & & $\mathrm{Fp}$ & LSD & \\
\hline Genotype (G) & $<0.001$ & 6.15 & & $<0.001$ & 5.36 & \\
\hline Protection (P) & 0.347 & NS & & $<0.001$ & 2.40 & \\
\hline $\mathrm{G} \times \mathrm{P}$ & 0.308 & NS & & 0.173 & NS & \\
\hline
\end{tabular}

UP, unprotected; CP, completely protected; - , not tested; Fp, probability of $F$-test; DAE, days after seedling emergence; LSD, least significant difference at $P<0.05$; NS, non-significant. Figures with the same letter in a column or row are not significantly different at $P<0.05$.

variety LK 861 . Leaf damage by the serpentine leaf miner during the 2003 cropping season was negligible. Leaf miner is an emerging pest problem on cotton in India, and there is a need to monitor the damage by this pest on transgenic crops so that it does not assume serious pest proportions in the absence of insecticide application for controlling the major pests such as $H$. armigera.

\subsubsection{Ash weevil}

Differences in numbers of ash weevil, M. undecimpustulatus were significant across genotypes and the protection levels during the 2004 cropping season (Table 10). The interaction effects were also significant. The numbers of weevils were lower on the transgenic hybrids than on their non-transgenic counterparts, but the differences were non-significant. The weevil numbers were lower in the protected than in the unprotected plots of Aravinda, MDL 2450, Mech 162, and Mech 184. Weevil numbers were lower on LK 861, both under protected and unprotected conditions as compared to the other genotypes tested. 
Table 9

Leaf damage by serpentine leaf miner, Liriomyza trifolii in Bt-transgenic and non-transgenic cultivars of Gossypium hirsutum and Gossypium arboreum (ICRISAT, Patancheru, 2002-2004)

\begin{tabular}{|c|c|c|c|c|c|c|c|c|c|}
\hline \multirow[t]{3}{*}{ Cultivar } & \multicolumn{9}{|c|}{ Leaf miner damaged leaves (\%) (30 DAE) } \\
\hline & \multicolumn{3}{|l|}{2002} & \multicolumn{3}{|l|}{2003} & \multicolumn{3}{|l|}{2004} \\
\hline & UP & $\mathrm{CP}$ & Mean & UP & $\mathrm{CP}$ & Mean & UP & $\mathrm{CP}$ & Mean \\
\hline \multicolumn{10}{|c|}{ Gossypium arboreum varieties } \\
\hline Aravinda & 5.7 & 4.4 & $5.1^{\mathrm{a}}$ & 13.0 & 9.0 & $11.0^{\mathrm{ab}}$ & 12.0 & 49.3 & $30.7^{\mathrm{ab}}$ \\
\hline MDL 2450 & 2.4 & 3.0 & $2.7^{\mathrm{a}}$ & 12.0 & 8.0 & $10.0^{\mathrm{a}}$ & 13.7 & 18.7 & $16.2^{\mathrm{a}}$ \\
\hline \multicolumn{10}{|c|}{ Gossypium hirsutum varieties } \\
\hline L 604 & 24.4 & 19.0 & $21.7^{\mathrm{b}}$ & 25.7 & 25.0 & $25.4^{\mathrm{bc}}$ & 67.3 & 61.7 & $64.5^{\mathrm{bcd}}$ \\
\hline LK 861 & 37.0 & 28.1 & $32.6^{\mathrm{c}}$ & 46.4 & 55.0 & $50.7^{\mathrm{def}}$ & 77.0 & 80.3 & $78.7^{\text {cde }}$ \\
\hline \multicolumn{10}{|c|}{ Gossypium hirsutum transgenic hybrids } \\
\hline Mech 12 & - & - & - & 54.4 & 53.0 & $53.7^{\mathrm{ef}}$ & 110.0 & 153.7 & $131.9^{\mathrm{e}}$ \\
\hline Mech 162 & 6.4 & 3.0 & $4.7^{\mathrm{a}}$ & 44.0 & 33.7 & $38.9^{\text {cd }}$ & 87.7 & 82.7 & $85.2^{\text {de }}$ \\
\hline Mech 184 & - & - & - & 17.7 & 16.0 & $16.9^{\mathrm{ab}}$ & 44.0 & 65.7 & $54.9^{\mathrm{bc}}$ \\
\hline \multicolumn{10}{|c|}{ Gossypium hirsutum non-transgenic hybrids } \\
\hline Mech 12 & - & - & - & 70 & 51.7 & $60.9^{\mathrm{f}}$ & 82.3 & 116.7 & $99.5^{\mathrm{de}}$ \\
\hline Mech 162 & 5.0 & 3.4 & $4.2^{\mathrm{a}}$ & 25.0 & 56.4 & $40.7^{\mathrm{de}}$ & 91.0 & 63.7 & $77.4^{\text {cde }}$ \\
\hline Mech 184 & - & - & - & 19.0 & 18.0 & $18.5^{\mathrm{ab}}$ & 52.3 & 48.7 & $50.5^{\mathrm{abc}}$ \\
\hline \multirow[t]{2}{*}{ Mean } & 13.5 & 10.2 & 11.8 & 32.7 & 32.6 & 32.7 & 63.7 & 74.1 & 68.9 \\
\hline & $\mathrm{Fp}$ & LSD & & $\mathrm{Fp}$ & LSD & & $\mathrm{Fp}$ & LSD & \\
\hline Genotype (G) & $<0.001$ & 7.53 & & $<0.001$ & 14.52 & & $<0.001$ & 35.43 & \\
\hline Protection $(\mathrm{P})$ & 0.066 & NS & & 0.967 & NS & & 0.193 & NS & \\
\hline $\mathrm{G} \times \mathrm{P}$ & 0.476 & NS & & 0.133 & NS & & 0.570 & NS & \\
\hline
\end{tabular}

UP, unprotected; CP, completely protected; - , not tested; Fp, probability of $F$-test; DAE, days after seedling emergence; LSD, least significant difference at $P<0.05 ; \mathrm{NS}$, non-significant. Figures with the same letter in a column are not significantly different at $P<0.05$.

\subsubsection{Whitefly}

There differences in whitefly, B. tabaci numbers were significant among the genotypes tested and the protection levels (Table 10). There were no differences in white fly numbers between the transgenic and non-transgenic hybrids. The whitefly numbers were either greater in protected plots or at par with unprotected plots. This may be because of mortality of generalist predators in plots under insecticide protection. Whitefly infestation was relatively lower on Aravinda, MDL 2450 and LK 861 than on the other genotypes tested.

\subsubsection{Green bug}

There were no differences in the numbers of green bugs, $N$. viridula among the genotypes tested (Table 11). The differences across protection levels and the interaction effects were significant. The numbers of green bugs were lower in unprotected plots possibly because of less foliage. There were no differences in the numbers of green bugs between the transgenic and the nontransgenic hybrids. However, the green bug numbers were quite low in both the protected and the unprotected plots.

\subsubsection{Red cotton bug}

There were no significant differences in the numbers of red cotton bug, D. koenigii on the genotypes tested (Table 11). However, the differences in numbers of red cotton bugs across protection levels were significant, while the interaction effects were non-significant. There were no red cotton bugs in plots under insecticide protection. The numbers of red cotton bugs were relatively lower on MDL 2450, LK 861, and Mech 12. There were no apparent differences in the relative abundance of red cotton bug between the transgenic and non-transgenic hybrids.

\section{Discussion}

Deployment of transgenic insect-resistant crops has reduced yield losses under severe infestation. On an average, farmers spray $15-20$ times to protect cotton and many other crops from the ravages of $H$. armigera. Transgenic crops can make a critical contribution in reducing the dosage and frequency of insecticide application. Brickle et al. (1999) suggested that insecticides are more effective in controlling bollworm damage even at lower rates of application on transgenic than on the 
Table 10

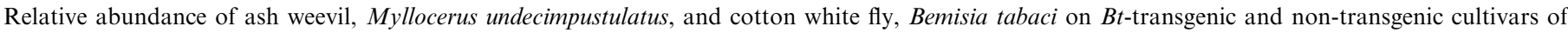
Gossypium hirsutum and Gossypium arboreum (ICRISAT, Patancheru, 2004)

\begin{tabular}{|c|c|c|c|c|c|c|}
\hline \multirow[t]{2}{*}{ Cultivar } & \multicolumn{3}{|c|}{ Number of ash weevils per five plants* } & \multicolumn{3}{|c|}{ Number of white flies per five plants ${ }^{* *}$} \\
\hline & UP & $\mathrm{CP}$ & Mean & UP & $\mathrm{CP}$ & Mean \\
\hline \multicolumn{7}{|c|}{ Gossypium arboreum varieties } \\
\hline Aravinda & $17.0^{\mathrm{de}}$ & $5.0^{\mathrm{abc}}$ & 11.0 & $17.7^{\mathrm{abc}}$ & $17.0^{\mathrm{abc}}$ & 17.4 \\
\hline MDL 2450 & $28.7^{\mathrm{f}}$ & $5.3^{\mathrm{abc}}$ & 17.0 & $13.3^{\mathrm{ab}}$ & $8.3^{\mathrm{a}}$ & 10.8 \\
\hline \multicolumn{7}{|c|}{ Gossypium hirsutum varieties } \\
\hline L 604 & $11.7^{\mathrm{bcd}}$ & $9.7^{\text {abcd }}$ & 10.7 & $23.0^{\mathrm{bcd}}$ & $44.3^{\mathrm{g}}$ & 33.7 \\
\hline LK 861 & $2.7^{\mathrm{a}}$ & $4.7^{\mathrm{b}}$ & 3.7 & $16.7^{\mathrm{abc}}$ & $17.0^{\mathrm{abc}}$ & 16.9 \\
\hline \multicolumn{7}{|c|}{ Gossypium hirsutum transgenic hybrids } \\
\hline Mech 12 & $6.7^{\mathrm{abc}}$ & $10.3^{\mathrm{abcd}}$ & 8.5 & $21.0^{\mathrm{bc}}$ & $39.7^{\mathrm{fg}}$ & 30.4 \\
\hline Mech 162 & $9.0^{\mathrm{abcd}}$ & $5.0^{\mathrm{abc}}$ & 7.0 & $17.0^{\mathrm{abc}}$ & $41.7^{\mathrm{g}}$ & 29.4 \\
\hline Mech 184 & $23.0^{\mathrm{e}}$ & $6.7^{\mathrm{abc}}$ & 14.9 & $24.0^{\text {bcde }}$ & $29.0^{\text {cdef }}$ & 26.5 \\
\hline \multicolumn{7}{|c|}{ Gossypium hirsutum non-transgenic hybrids } \\
\hline Mech 12 & $6.3^{\mathrm{abc}}$ & $13.0^{\mathrm{cd}}$ & 9.7 & $26.7^{\text {cde }}$ & $40.7^{\mathrm{fg}}$ & 33.7 \\
\hline Mech 162 & $15.3^{\mathrm{de}}$ & $11.3^{\mathrm{bcd}}$ & 13.3 & $22.7^{\text {bcd }}$ & $35.0^{\text {defg }}$ & 28.9 \\
\hline Mech 184 & $17.0^{\mathrm{de}}$ & $11.0^{\mathrm{bcd}}$ & 14.9 & $22.0^{\mathrm{bc}}$ & $36.3^{\text {efg }}$ & 29.2 \\
\hline \multirow[t]{2}{*}{ Mean } & 13.7 & 8.2 & 11.0 & 20.4 & 30.9 & 25.7 \\
\hline & $\mathrm{Fp}$ & LSD & & $\mathrm{Fp}$ & LSD & \\
\hline Genotype (G) & 0.001 & 5.70 & & $<0.001$ & 8.81 & \\
\hline Protection (P) & $<0.001$ & 2.55 & & $<0.001$ & 3.94 & \\
\hline $\mathrm{G} \times \mathrm{P}$ & $<0.001$ & 8.06 & & 0.016 & 12.46 & \\
\hline
\end{tabular}

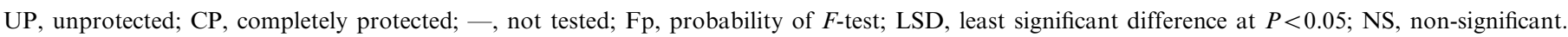
Figures with the same letter in a column or row are not significantly different at $P<0.05$.

*Number of ash weevils recorded on 60,45, 60, 75, and 90 days after seedling emergence (pooled data).

**N Number of white flies recorded on 90, 110, and 130 days after seedling emergence (pooled data).

non-transgenic cultivars. In the present studies, transgenic hybrids in combination with insecticides resulted in greater seed cotton yield than the non-transgenic hybrids at high levels of $H$. armigera infestation during the 2004 rainy season. However, the advantage of the transgene was not apparent at low to moderate levels of infestation during the 2002 and 2003 cropping seasons, except in the transgenic hybrid Mech 184. Some of the differences in oviposition, larval density, and the numbers of sucking insects during the early part of the cropping season between the genotypes tested or across protection regimes may also be due to differences in plant canopy and the numbers of fruiting bodies. However, for purposes of interpretation of the results, the effects of protection regimes on plant canopy or amongst the genotypes were considered as part of the genotypic or treatment effects.

Egg laying was numerically greater on the transgenic hybrids than on the non-transgenic counterparts possibly because of better leaf canopy of the former due to low damage by the target and non-target insects. Oviposition and larval density were also lower on the $G$. arboreum genotypes, Aravinda and MDL 2450 as compared to the non-transgenic hybrid, Mech 162. Transgenic cottons with $B t$ genes have earlier been reported to show adverse affects on survival and development of $H$. armigera in Asia $(\mathrm{Ni}$ et al., 1996; Zhao et al., 1998; Guo et al., 1999; Bambawale et al., 2004). Differences in larval density on the transgenic and non-transgenic hybrids were not large, except during the 2004 rainy season under high levels of $H$. armigera infestation. One of the reasons for this may be the low expression of $B t$ toxins toward the end of the cropping season during boll formation (Kranthi et al., 2005). However, there were significant differences in seed cotton yield between the transgenic and non-transgenic hybrids, and across protection regimes. This raises a basic question about the use of larval numbers as a criterion for economic thresholds for pest management in cotton and other crops.

Helicoverpa armigera damage in squares was lower in the transgenic hybrids than in the non-transgenic counterparts under protected and unprotected conditions, though the differences were not significant in some cases. Square damage was also significantly lower on the $G$. arboreum varieties Aravinda and MDL 2450. Similarly, the transgenic hybrids suffered lower boll damage than their nontransgenic counterparts. However, differences in many cases were not statistically significant. Bollworm damage was also lower in the G. arboreum varieties, Aravinda and 
Table 11

Relative abundance of green bug, Nezara viridula and red cotton bug, Dysdercus koenigii on Bt-transgenic and non-transgenic cultivars of Gossypium hirsutum and Gossypium arboreum (ICRISAT, Patancheru, 2004)

\begin{tabular}{|c|c|c|c|c|c|c|}
\hline \multirow[t]{2}{*}{ Cultivar } & \multicolumn{3}{|c|}{ Number of green bugs per five plants* } & \multicolumn{3}{|c|}{ Number of red cotton bugs per five plants** } \\
\hline & UP & $\mathrm{CP}$ & Mean & UP & $\mathrm{CP}$ & Mean \\
\hline \multicolumn{7}{|c|}{ Gossypium arboreum varieties } \\
\hline Aravinda & $4.0^{\text {abcdef }}$ & $2.7^{\text {abcde }}$ & 3.4 & 7.7 & 0.0 & 3.9 \\
\hline MDL 2450 & $5.7^{\mathrm{def}}$ & $4.7^{\text {bcdef }}$ & 5.2 & 3.7 & 0.0 & 1.9 \\
\hline \multicolumn{7}{|c|}{ Gossypium hirsutum varieties } \\
\hline L 604 & $1.7^{\mathrm{abcd}}$ & $6.0^{\mathrm{def}}$ & 3.9 & 12.7 & 0.0 & 6.4 \\
\hline LK 861 & $0.3^{\mathrm{ab}}$ & $6.7^{\mathrm{ef}}$ & 3.5 & 1.0 & 0.0 & 0.5 \\
\hline \multicolumn{7}{|c|}{ Gossypium hirsutum transgenic hybrids } \\
\hline Mech 12 & $0.0 \mathrm{a}$ & $6.0^{\mathrm{def}}$ & 3.0 & 1.7 & 0.0 & 0.9 \\
\hline Mech 162 & $1.3^{\mathrm{abc}}$ & $3.0^{\text {abcde }}$ & 2.2 & 33.3 & 0.0 & 16.7 \\
\hline Mech 184 & $8.3^{\mathrm{f}}$ & $5.0^{\text {bcdef }}$ & 6.7 & 12.3 & 0.0 & 6.2 \\
\hline \multicolumn{7}{|c|}{ Gossypium hirsutum non-transgenic hybrids } \\
\hline Mech 12 & $1.0^{\mathrm{abc}}$ & $3.0^{\text {abcde }}$ & 2.0 & 4.0 & 0.0 & 2.0 \\
\hline Mech 162 & $2.3^{\mathrm{abcd}}$ & $5.3^{\text {cdef }}$ & 3.8 & 2.7 & 0.0 & 1.4 \\
\hline Mech 184 & $4.7^{\text {bcdef }}$ & $4.0^{\mathrm{abcdef}}$ & 4.4 & 25.0 & 0.0 & 12.5 \\
\hline \multirow[t]{2}{*}{ Mean } & 2.9 & 4.6 & 3.8 & $10.4^{\mathrm{B}}$ & $0.0^{\mathrm{A}}$ & 5.2 \\
\hline & $\mathrm{Fp}$ & LSD & & $\mathrm{Fp}$ & LSD & \\
\hline Genotype (G) & 0.137 & NS & & 0.685 & NS & \\
\hline Protection (P) & 0.017 & 1.38 & & 0.014 & 8.20 & \\
\hline$G \times P$ & 0.036 & 4.37 & & 0.685 & NS & \\
\hline
\end{tabular}

UP, unprotected; CP, completely protected; - , not tested; Fp, probability of $F$-test; LSD, least significant difference at $P<0.05$; NS, non-significant. Figures with the same letter in a column or row are not significantly different at $P<0.05$.

${ }^{*}$ Number of Nezara viridula recorded on 110 days after seedling emergence.

**N Number of red cotton bugs recorded on 130 days after seedling emergence.

MDL 2450 under insecticide protection than in the nontransgenic hybrid Mech 12. The results suggested that conventional $G$. arboreum varieties were as effective in minimizing the insect damage as the $B t$-transgenic hybrids. Since first-instar larvae prefer to feed inside the squares and flowers before feeding on the bolls, it is important to have adequate levels of expression of the $B t$ toxins in flower buds and flowers. However, the amounts of $B t$ toxins in squares of Mech 162 and Mech 184 were low or below detectable levels at 110 days after crop emergence (Kranthi et al., 2005). Corn earworm (Helicoverpa zea (Boddie) and tobacco budworm Heliothis virescens $\mathrm{F}$.) survival has been found to be greater on squares and flower anthers than on other floral structures in Deltapine 5415 conventional cotton and transgenic NuCOTN 33B (Gore et al., 2001). ELISA tests have indicated that $\mathrm{cryl} A c$ expression varied in different plant parts, but bollworm survival did not correlate with the protein expression (Gore et al., 2001). Since there are some problems associated with expression of $B t$ toxins in flowers under the control of $C a M V 35 S$ promoter, it would be useful use tissue specific or inducible promoters for effective control of $H$. armigera (Sharma et al., 2004). At the same time, it may be useful to deploy the $B t$ genes in cultivars derived through conventional breeding, which have oviposition non-preference and antibiosis as components of resistance to the target and non-target insects.

The differences in seed cotton yield between the transgenic and non-transgenic hybrids (except in case of Mech 184) were not significant during the 2002 and 2003 cropping seasons under low to moderate levels of $H$. armigera infestation. The seed cotton yield of $G$. arboreum varieties Aravinda and MDL 2450 was at times significantly greater than that of transgenic or non-transgenic hybrids, although there were a few exceptions. The seed cotton yield of the second flush in transgenic hybrids was greater under unprotected conditions than under protected conditions. Among the three transgenic hybrids tested, seed cotton yield of Mech 184 was greater than that of the other hybrids tested, despite the fact that it was preferred for oviposition by $H$. armigera, and suffered greater square and boll damage than the other hybrids tested. Because of longer duration and resistance to jassids, its yield potential was greater than the other hybrids tested. Therefore, it is important to combine resistance to $H$. armigera through genetic transformation with resistance to other important insect pests based on conventional host plant resistance in an ideal plant type or deploy the 
transgenic cultivars in combination with other components of pest management.

Terminal shoot damage by $E$. vittella was significantly lower in the transgenic hybrids as compared to the nontransgenic ones. The effectiveness of the transgene against shoot damage by spotted bollworm will delay the onset of pesticide sprays, and thus, provide more time for population increase of the parasites and predators to exercise greater control on insect pests, particularly the soft bodied sucking insects in the cotton ecosystem. There was no evidence of increased susceptibility or resistance of the transgenic Bt cottons to the jassid, A. biguttula biguttula, serpentine leaf miner, $L$. trifolii, cotton white fly, B. tabaci, green bug, $N$. viridula and red cotton bug, D. koenigii. The numbers of ash weevil and the white fly were lower on MDL 2450 and LK 861 than on the other genotypes tested. Incidence of cotton jassid and the serpentine leaf miner was also lower on the $G$. arboreum varieties Aravinda and MDL 2450 as compared to the G. hirsutum varieties L 604 and LK 861. The G. arboreum genotypes are known to be resistant to jassids (Sharma and Agarwal, 1983b), and can serve as a useful source of resistance genes against this pest, for which no toxin genes have been identified for use in genetic transformation. Since, this is one of the key pests of cotton in Asia, it is important that varieties to be deployed commercially (transgenic or non-transgenic) have adequate levels of resistance to this pest. However, plant hairiness, which confers resistance to jassids (Ambekar and Kalbhor, 1981; Sharma and Agarwal, 1983b), also imparts oviposition preference for E. vittella (Sharma and Agarwal, 1983a) and $H$. armigera (Bhat and Jayaswal, 1988). Therefore, it is important to identify other physico-chemical factors such as thickness of the cell wall, the distance between epidermis and the phloem bundles where the jassids feed, and chemical factors that confer resistance to cotton jassid, but do not provide an adaptive advantage to bollworms.

Because of the greater susceptibility of some of the transgenic hybrids to jassids, and the relatively early maturity (except Mech 184), the advantage of transgenics over the commercial varieties was not evident, except under high levels of $H$. armigera infestation during the 2004 cropping season. Therefore, for transgenic cottons to be an important component in integrated pest management, it is important to transform varieties or hybrid parents that have less susceptibility to the target and/or non-target insect pests to reduce the number of insecticide application for sustainable crop protection.

\section{Acknowledgements}

We thank Mahyco Hybrid Seed Company for providing the seed of the transgenic hybrids, and S.V. Narayanchandra, K. Hareendranath, Madhusudhan Reddy, J. Raja Rao and V. Venkateswara Rao for their technical support in these studies.

\section{References}

Ambekar, J.S., Kalbhor, S.E., 1981. Note on the plant characters associated with resistance to jassid, Amrasca biguttula biguttula Ishida, in different varieties of cotton. Indian J. Agric. Sci. 51, 816-817.

Armes, N.J., Jadhav, D.R., DeSouza, K.R., 1996. A survey of insecticide resistance in Helicoverpa armigera in the Indian sub-continent. Bull. Entomol. Res. 86, 499-514.

Bambawale, O.M., Singh, A., Sharma, O.P., Bhosle, B.B., Lavekar, R.C., Dhandapani, A., Kanwar, V., Tanwar, R.K., Rathod, K.S., Patange, N.R., Pawar, V.M., 2004. Performance of Bt cotton (Mech 162) under integrated pest management in farmers' participatory field trial in Nanded district, Central India. Curr. Sci. 86, 1628-1633.

Barton, K., Whiteley, H., Yang, N.S., 1987. Bacillus thuringiensis $\delta$ endotoxin in transgenic Nicotiana tabacum provides resistance to lepidopteran insects. Plant Physiol. 85, 1103-1109.

Benedict, J.H., Sachs, E.S., Altman, D.W., Deaton, D.R., Kohel, R.J., Ring, D.R., Berberich, B.A., 1996. Field performance of cotton expressing Cry IA insecticidal crystal protein for resistance to Heliothis virescens and Helicoverpa zea (Lepidoptera: Noctiudae). J. Econ. Entomol. 89, 230-238.

Bhat, M.G., Jayaswal, A.P., 1988. A study on factors of bollworm resistance in cotton (Gossypium hirsutum L.) using isogenic lines. J. Indian Soc. Cotton Improv. 13, 149-153.

Brickle, D.S., Turnipseed, S.G., Sullivan, M.J., Dugger, P., 1999. The efficacy of different insecticides and rates against bollworms (Lepidoptera: Noctuidae) in B.T. and conventional cotton. In: Richter, D. (Ed.), Proceedings of the Beltwide Cotton Production and Research Conference, 3-7 January 1999, Orlando, FL, USA, vol. 2. National Cotton Council, Memphis, USA, pp. 934-936.

Cui, J.J., Xia, J.Y., 1999. Effects of transgenic Bt cotton on development and reproduction of cotton bollworm. Acta Agric. Univ. Henan 33, 20-24.

Fitt, G.P., 1989. The ecology of Heliothis species in relation to agroecosystems. Annu. Rev. Entomol. 34, 17-52.

Fitt, G.P., 2003. Deployment and impact of transgenic Bt cottons in Australia. In: Kalaitzandonakes, N.G. (Ed.), The Economic and Environmental Impacts of Agbiotech: a Global Perspective. Kluwer Academic Press, New York, USA, pp. 141-164.

Flint, H.M., Henneberry, T.J., Wilson, F.D., Holguin, E., Parks, N., Buehler, R.E., 1995. The effects of transgenic cotton, Gossypium hirsutum L.; containing Bacillus thuringiensis toxin genes for the control of the pink bollworm, Pectinophora gossipiella (Saunders) Lepidoptera, Gelechiidae and other arthropods. Southwest. Entomol. 20, 281-292.

Gore, J., Leonard, B.T., Adamczyk, J.J., 2001. Bollworm (Lepidoptera: Noctuidae) survival on Bollgard and Bollgard II cotton flower bud and flower components. J. Econ. Entomol. 94, 1445-1451.

Greenplate, J.T., 1999. Quantification of Bacillus thuringiensis insect control protein Cry1A(c) over time in Bollgard cotton fruit and terminals. J. Econ. Entomol. 92, 1377-1383.

Guo, S.D., Cui, H.Z., Xia, L.Q., Wu, D.L., Ni, W.C., Zhang, Z.L., Zhang, B.L., Xu, Y.J., 1999. Development of bivalent insect-resistant transgenic cotton plants. Sci. Agric. Sin. 32, 1-7.

Hilder, V.A., Boulter, D., 1999. Genetic engineering of crop plants for insect resistance - a critical review. Crop Prot. 18, 177-191.

James, C., 2003. Preview: Global Status of Commercialized Transgenic Crops: 2003. ISAAA Briefs no. 30. International Service for Acquisition on Agri-Biotech Applications (ISAAA), Ithaca, New York, USA http://www.isaaa.org/Publications/briefs_26.htm.

Kranthi, K.R., Jadhav, D.R., Kranthi, S., Wanjari, R.R., Ali, S.S., Russell, D.A., 2002. Insecticide resistance in five major insect pests of cotton in India. Crop Prot. 21, 449-460.

Kranthi, K.R., Naidu, S., Dhawad, C.S., Tatwawadi, A., Mate, K., Patil, E., Bharose, A.A., Behere, G.T., Wadaskar, S.M., Kranthi, S., 2005. Temporal and intra-plant variability of CrylAc expression in Btcotton and its influence on the survival of cotton bollworm, 
Helicoverpa armigera (Hubner) (Noctuidae: Lepidoptera). Curr. Sci. 89, 291-298.

Matthews, M., 1999. Heliothine Moths of Australia. A Guide to Pest Bolllworms and Related Noctuid Groups. Monograph on Australian Lepidoptera, vol. 7. Commonwealth Scientific and Industrial Research Organization (CSIRO) Publishing, 150 Oxford Street, Callingford, Vic., 3066, Australia (320pp).

McCaffery, A.R., King, A.B.S., Walker, A.J., El-Nayir, H., 1989. Resistance to synthetic pyrethroids in the bollworm, Heliothis armigera from Andhra Pradesh, India. Pestic. Sci. 27, 65-76.

Ni, W.C., Huang, J.Q., Guo, S.D., Shu, C.G., Wu, J.Y., Wang, W.G., Zhang, Z.L., Chen, S., Mao, L.Q., Wang, Y., Xu, Y.J., Gu, L.M., Zhou, B.L., Shen, X.L., Xiao, S.H., 1996. Transgenic bollwormresistant cotton plants containing the synthetic gene coding Bacillus thuringiensis insecticidal protein. Jiangsu J. Agric. Sci. 12, 1-6.

Qaim, M., Zilberman, D., 2003. Yield effects of genetically modified crops in developing countries. Science 299, 900-902.

Schell, J., 1997. Cotton carrying the recombinant insect poison $B t$ toxin: no case to doubt the benefits of plant biotechnology. Curr. Opin. Biotechnol. 8, 235-236.

Sharma, H.C., 2001. Crop Protection Compendium: Helicoverpa armigera. Electronic Compendium for Crop Protection. Commonwealth Agricultural Bureau International, Wallingford, UK.

Sharma, H.C., Agarwal, R.A., 1983a. Ovipositional behavior of spotted bollworm, Earias vittella Fab. on some cotton genotypes. Insect Sci. Appl. 4, 373-376.
Sharma, H.C., Agarwal, R.A., 1983b. Role of some chemical components and leaf hairs in varietal resistance in cotton to jassid, Amrasca biguttula biguttula Ishida. J. Entomol. Res. 7, 145-149.

Sharma, H.C., Ortiz, R., 2002. Host plant resistance to insects: an ecofriendly approach for pest management and environment conservation. J. Environ. Biol. 23, 111-135.

Sharma, H.C., Sharma, K.K., Seetharama, N., Ortiz, R., 2000. Prospects for using transgenic resistance to insects in crop improvement. Electron. J. Biotechnol. 3 (2) http://www.ejb.org/content/vol 3/issue $2 /$ full $/ 20$

Sharma, H.C., Sharma, K.K., Seetharama, N., Crouch, J.H., 2004. Genetic engineering of crops for insect control: effectiveness and strategies for gene deployment. CRC Crit. Rev. Plant Sci. 23, 47-72.

Sundramurthy, V.T., Chitra, K.L., 1992. Integrated pest management in cotton. Indian J. Plant Prot. 20, 1-17.

Vaeck, M., Reynaerts, A., Hofte, H., Jansens, S., DeBeuckleer, M., Dean, C., Zabeau, M., Van Montagu, M., Leemans, J., 1987. Transgenic plants protected from insect attack. Nature 327, 33-37.

Wilson, W.D., Flint, H.M., Deaton, R.W., Fischhoff, D.A., Perlak, F.J., Armstrong, T.A., Fuchs, R.L., Berberich, S.A., Parks, N.J., Stapp, B.R., 1992. Resistance of cotton lines containing a Bacillus thuringiensis toxin to pink bollworm (Lepidoptera: Gelechiidae) and other insects. J. Econ. Entomol. 85, 1516-1521.

Zhao, J.Z., Zhao, K.J., Lu, M.G., Fan, X.L., Guo, S.D., 1998. Interactions between Helicoverpa armigera and transgenic Bt cotton in North China. Sci. Agric. Sin. 31, 1-6. 